\title{
VAV2 Gene
}

National Cancer Institute

\section{Source}

National Cancer Institute. VAV2 Gene. NCI Thesaurus. Code C18361.

This gene plays a role in signal transduction and neg ative regulation of T-cell activation. 